\title{
A STUDY ON IMPACT OF TRAINING AND DEVELOPMENT FOR EMPLOYEES IN LATLON TECHNOLOGIES PVT. LTD( DrNGPASC 2019- 2020 COIM008)
}

KEY WORDS: Employees, Impact, Training and Development
Dr. S. Gandhimathi

C. Karthick*

Dr. R. Guna Sundari

\section{P. Vimal kumar}

\section{B. Kalaivani}

Assistant Professor, Department of Commerce, Dr. N. G. P. Arts and Science College, Coimbatore -48

Assistant Professor, Department of Commerce, Dr. N. G. P. Arts and Science College, Coimbatore $-48 *$ Corresponding Author

Assistant Professor, Department of Commerce, Dr. N. G. P. Arts and Science College, Coimbatore -48

Assistant Professor, Department of Commerce, Dr. N. G. P. Arts and Science College, Coimbatore -48

M. Com., Department of Commerce, Dr. N. G. P. Arts and Science College, Coimbatore -48

터 Human resource has become strategic resource to gain sustainable competitive advantages in this age of globalization. Human resource regards training and development as a function concerned with organisational activity aimed at bettering the job performance of individuals and groups in organizational settings. Training and development can be described as an "educational process which involves the sharpening of skills, concepts, changing of attitude and gaining more knowledge to enhance the performance of employees". This study is covered by Impact of Training and Development for Employees.

\section{STATEMENT OFTHE PROBLEM}

Employee training is becoming an important factor for organizations' success world over. The costs of employee training are high but of course these costs are far lesser than high profits which can be achieved through proper training. Most of the companies are encountered many problems regarding their employees like absenteeism, turnover, lack of commitment, motivation and capabilities, having insufficient knowledge and skills etc. So it is important to study the impact on trainings provided to their employees.

\section{OBJECTIVES OFTHE STUDY}

- To study the socio-economic profile of the employees.

- To identify the training and development contribution towards their individual performance.

- To determine the impact of training and development on employee performance and effectiveness.

- To identify the level of satisfaction of employees in training.

\section{SCOPE OFTHE STUDY}

This study will be helpful in identifying the impact of training and development on employees performance among the employees of Latlon Technologies Pvt.Ltd.

\section{RESEARCH METHODOLOGY}

A research in common refers to the search for knowledge. The study confined to Employees of Latlon Technologies Pvt. Ltd. In this regard both male and female different categories of employees.

\section{RESEARCH DESIGN}

Research design is a logical and systematic plan prepared for directing a research study. It specifies the objective of the study, methodology and techniques to be obtained in the study. The study consists of descriptive and analytical research.

\section{SAMPLE SIZE}

The sample is the place where the study has been carried out. The study covers the employees of all levels in the Latlon Technologies Pvt. Ltd. The total sample size for the study is 200.

\section{SAMPLING METHOD}

Convenient sampling techniques has been used to select the respondents.Non probability sample design.

\section{SOURCE OF DATA COLLECTION}

Both primary and secondary datas are used for the data collection.

\section{TOOLS FOR ANALYSIS}

The statistical tools used for the study are:

Simple Percentage Method

Rank Analysis

Chi-Square Test

One way ANOVA

\section{REVI EW OF LITE RAT URE}

Shouvik Sanyal (2018)2 studies the impact of Training and Development practices on the employee performance in the select Omani Public and Private sector banking organizations. The aim of the paper is to analyze the impact of training and development practices on employee performance. He concludes that Training and Development Practices have a positive influence on employee performance in the Omani Banking Industry Halidu Salihu Gambo (2015) has made a study on The Impact of Training and Development on Workers' Productivity. Staff training and development is a key to achieving organizational success and corporate development. His study is aimed at finding out the Impact of Training and Development on workers' productivity via the TET Fund Academic Staff Training and Development 2010 Sponsorship. His Results revealed that training and development programmes improve employees' skills and performance at work place, enhance their technical knowhow/wherewithal to with stand the challenges of contemporary times, thus, an effective tool for sustaining and enhancing workers' productivity in the academia.

Pallavi P. Kulkarni (2013)21 has made a focuse and analysed the literature findings on importance of training and development and its relation with the employees' quality of work life. training and development programs help in improving the employee behaviour and attitude towards the job and also uplift their morale. Thus, employee training and development programs are important aspects which are 
needed to be studied and focused on.

Debra L. Truitt (2011)23 explores the relationship between training experiences and attitudes about perceived job proficiency. He took a sample of 237 full-time salaried/exempt and hourly/non-exempt employees from one academic institution and three businesses in the states of Maryland, Delaware, and Arizona, the author finds a direct relationship between one's positive training experiences and attitudes and one's proficiency.

\section{PROCESS OFTRAINING AND DEVELOPMENT}

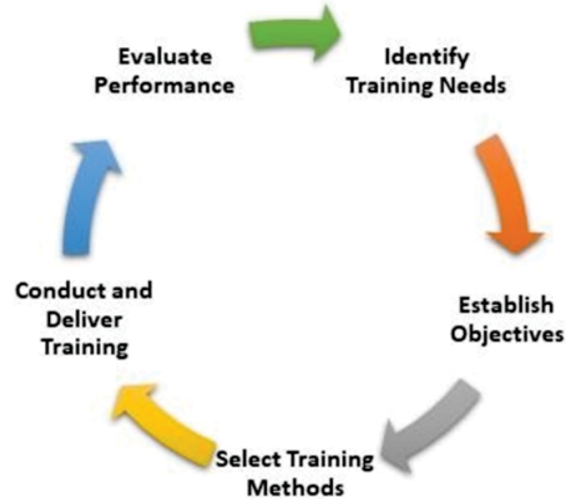

Training Programmes Conducting Period For The Respondents

\begin{tabular}{|c|c|c|c|}
\hline S. No. & FACTORS & FREQUENCY & PERCENT \\
\hline 1 & Every month & 45 & 22.5 \\
\hline 2 & Quarterly & 75 & 37.5 \\
\hline 3 & Half-yearly & 57 & 28.5 \\
\hline 4 & Once in year & 23 & 11.5 \\
\hline & Total & $\mathbf{2 0 0}$ & $\mathbf{1 0 0}$ \\
\hline
\end{tabular}

(Source:Primary Data)

From the above table, it can be shown that $37.5 \%$ of the employees are undergoing training 3 months once, $22.5 \%$ of the employees were undergone training half-yearly, $22.5 \%$ of the employees undergone training for monthly once and remaining $11.5 \%$ of the employees undergone training yearly once.Hence, most (37.5) of the employees are undergone training at least 3 months once.

\section{Impact OfTraining Program For The Respondents}

\begin{tabular}{|c|c|c|c|}
\hline S. No & FACTORS & FREQUENCY & PERCENT \\
\hline 1 & Excellent & 36 & 18 \\
\hline 2 & Very good & 69 & 34.5 \\
\hline 3 & Good & 92 & 46 \\
\hline 4 & Very poor & 3 & 1.5 \\
\hline & Total & $\mathbf{2 0 0}$ & $\mathbf{1 0 0}$ \\
\hline
\end{tabular}

(Source:Primary Data)

\section{INTREPRETATION:}

From the above table, it can be showed that $46 \%$ of employees says that they had good impact on their work performance, $34.5 \%$ of employees says very good impact on their work performance, $18 \%$ of the employees says they had excellent impact on their work performance, $1.5 \%$ says they had a very poor performance on their work performance.Hence, most $(46 \%)$ of the employees says that they had a good impact on their work performance.

\section{The Impact OfTraining And Development}

\begin{tabular}{|l|c|c|c|}
\hline \multicolumn{1}{|c|}{ FACTORS } & SUM & MEAN & RANK \\
\hline Awareness building & 1087 & 5.435 & 6 \\
\hline Skill \& knowledge gaining & 1045 & 5.225 & 9 \\
\hline Motivation & 1148 & 5.74 & 3 \\
\hline
\end{tabular}

\begin{tabular}{|l|c|c|c|}
\hline Develop employee relationship & 1107 & 5.535 & 5 \\
\hline $\begin{array}{l}\text { Effectiveness in improving skill } \\
\text { sproce }\end{array}$ & 1179 & 5.895 & 1 \\
\hline Breaks out of your comfort zone & 1162 & 5.81 & 2 \\
\hline Better focus towards the project & 1115 & 5.575 & 4 \\
\hline $\begin{array}{l}\text { Build positive attitude among } \\
\text { employees }\end{array}$ & 1033 & 5.165 & 10 \\
\hline Stress free work environment & 1058 & 5.29 & 8 \\
\hline
\end{tabular}

(Source:Primary Data)

\section{INTREPRETATION:}

From the above table, it shows that effectiveness in improving skill is ranked as First, followed by breaks out of your comfort zone holds the Second rank, improving motivation holds Third rank, better focus towards the project holds the Fourth rank, develop employee relationship holds the Fifth rank, awareness building holds the Sixth rank, improves the learning skill at new space holds the Seventh rank, stress free environment holds the Eighth rank, skill and knowledge gaining holds the Ninth rank, and finally builds positive attitude among employees holds the Tenth rank.

\section{Comparision Between Experience And Contribution} Towards Individual Performance

HO $=$ There is no mean difference between experience and contribution towards individual performance.

$\mathbf{H 1}=$ There is a mean difference between experience and contribution towards individual performance

\begin{tabular}{|c|c|c|c|c|c|c|}
\hline Factors & & \begin{tabular}{|l|} 
Sum Of \\
Squares
\end{tabular} & $\mathrm{DF}$ & $\begin{array}{l}\text { Mean } \\
\text { Square }\end{array}$ & $F$ & SIG. \\
\hline \multirow{3}{*}{$\begin{array}{l}\text { Improve } \\
\text { employer } \\
\text { employee } \\
\text { relationship }\end{array}$} & \begin{tabular}{|l|} 
Between \\
Groups
\end{tabular} & 3.223 & 3 & 1.074 & \multirow[t]{3}{*}{1.552} & \multirow[t]{3}{*}{0.202} \\
\hline & \begin{tabular}{|l} 
Within \\
Groups
\end{tabular} & 135.652 & 196 & 0.692 & & \\
\hline & Total & 138.875 & 199 & & & \\
\hline \multirow[t]{3}{*}{$\begin{array}{l}\text { Improve work } \\
\text { efficiency }\end{array}$} & $\begin{array}{l}\text { Between } \\
\text { Groups }\end{array}$ & 6.898 & 3 & 2.299 & \multirow[t]{3}{*}{2.502} & \multirow[t]{3}{*}{0.061} \\
\hline & $\begin{array}{l}\text { Within } \\
\text { Groups }\end{array}$ & 180.097 & 196 & 0.919 & & \\
\hline & Total & 186.995 & 199 & & & \\
\hline \multirow{3}{*}{$\begin{array}{l}\text { Contributes } \\
\text { towards } \\
\text { personal } \\
\text { growth }\end{array}$} & $\begin{array}{l}\text { Between } \\
\text { Groups }\end{array}$ & 3.316 & 3 & 1.105 & \multirow[t]{3}{*}{1.340} & \multirow[t]{3}{*}{0.263} \\
\hline & $\begin{array}{l}\text { Within } \\
\text { Groups }\end{array}$ & 161.704 & 196 & 0.825 & & \\
\hline & Total & 165.020 & 199 & & & \\
\hline \multirow{3}{*}{$\begin{array}{l}\text { Encouraged to } \\
\text { determine our } \\
\text { own career and } \\
\text { development }\end{array}$} & \begin{tabular}{|l|} 
Between \\
Groups
\end{tabular} & 2.646 & 3 & 0.882 & \multirow[t]{3}{*}{1.244} & \multirow[t]{3}{*}{0.295} \\
\hline & $\begin{array}{l}\text { Within } \\
\text { Groups }\end{array}$ & 138.909 & 196 & 0.709 & & \\
\hline & Total & 141.555 & 199 & & & \\
\hline \multirow[t]{3}{*}{$\begin{array}{l}\text { Increase } \\
\text { motivation level }\end{array}$} & $\begin{array}{l}\text { Between } \\
\text { Groups }\end{array}$ & 3.715 & 3 & 1.238 & \multirow[t]{3}{*}{\begin{tabular}{|l|l|}
1.737 \\
\end{tabular}} & \multirow[t]{3}{*}{0.161} \\
\hline & \begin{tabular}{|l|} 
Within \\
Groups
\end{tabular} & 139.705 & 196 & 0.713 & & \\
\hline & Total & 143.420 & 199 & & & \\
\hline
\end{tabular}

(Source:Primary Data)

\section{INTREPRETATION:}

The above table shows the mean difference between experience and contribution towards individual performance.

1) The calculated value (0.202) is greater than the significant value (0.05), so the null hypothesis is accepted. We can conclude that there is no mean difference between experience and contribution towards individual performance in improving employer employee relationship.

2) The calculated value (0.061) is greater than the significant value (0.05), so the null hypothesis is accepted. We can conclude that there is no mean difference between 
experience and contribution towards individual performance in improving work efficiency.

3) The calculated value (0.263) is greater than the significant value $(0.05)$, so the null hypothesis is accepted. We can conclude that there is no mean difference between experience and contribution towards personal growth.

4) The calculated value (0.295) is greater than the significant value (0.05), so the null hypothesis is accepted.We can conclude that there is no mean difference between experience and contribution towards individual performance in encouraging to determine own career and development.

5) The calculated value (0.161) is greater than the significant value (0.05), so the null hypothesis is accepted. We can conclude that there is no mean difference between experience contribution towards individual performance in increasing motivation level.

\section{FINDINGS, SUGGESTIONS AND CONCLUSION}

- Most (37.5) of the employees are undergone training at least 3 months once.

- Most (46\%) of the employees says that they had a good impact on their work performance.

- From the rank analysis it is concluded that it shows that effectiveness in improving skill is ranked as First

\section{CONCLUSION}

The need for training \& development is determined by the employees performance deficiency Training enables the employees to develop their skills within the organization and hence naturally helps to increase the organizations market value, earning power of the employees and job security of the employees. Training and Development programs improve the quality of work-life by creating an employee supportive workplace. Training program brought positive impact on employee behaviour. The overall findings of the study conclude that Latlon technologies should concentrate more on training and development for their employees. They should identify each and every employee's skill and lack and then give training according to their needs.

\section{REFERENCES:}

1) Gambo, H. S. (2015). The Impact of Training and Development on Workers Productivity. Review of Public Administration and Management, 03(01), 1-4. https://doi.org/10.4172/2315-7844.1000160

2) Sanyal, S., \& Wamique Hisam, M. (2018). Impact of Training and Development on the Performance of Employees - A Comparative Study on Select Banks in Sultanate Of Oman. International Journal of Scientific Research and Management, 6(03), 191-198.https://doi.org/10.18535/ijsrm/v6i3.

3) Pallavi, M., \& Kulkarni,P. (2013). A literature review on training \& development and quality of work life.International Refereed Research Journal. Www. Researchersworld. Com, 136137 (22), 136-143. https://doi.org/10.1080/20786204.2013.108743

4) Truitt,D.L. (2011). Effect of training and development on employee attitude as it relates to training and work proficiency. SAGE Open, 1(3), 1-13. https://doi.org/10.1177/2158244011433338.

5) Kothari. C.R. (2004) Research methodology, Methods and Techniques, Third Edition, New Age International Publishers, New Delhi.

6) Gupta S.P. (2011) Statistical Methods, forty first Edition, Sultan Chand \& Sons, New Delhi.

7) Gupta C.B. (2011) Human Resource Management, Thirteenth Edition, Sultan \& Chand Sons, New Delhi. 